9. Olshen, S. R. (1987). The disappearance of giftedness in girls : An intervention strategy. Roeper Rev. No.9. pp. 251-254. [in English].

10. Polytsiak, N. I. (2021). Vplyv hendernykh stereotypiv na sotsializatsiiu obdarovanykh divchatok [The influence of gender stereotypes on the socialization of gifted girls]. Obdarovani dity - skarb natsii: materialy II Mizhnarodnoi naukovopraktychnoi onlain-konferentsii (18-22 serpnia 2021 roku) - Gifted children - the treasure of the nation: materials of the II International scientificpractical online conference (August 18-22, 2021). Kyiv. [in Ukrainian].

11. Popova, L. V. (2001). Gendernaya sotsializatsiya $\mathrm{v}$ detstve [Gender socialization in childhood]. Gender approach in preschool pedagogy: theory and practice: monograph: in 2 hours.Murmansk. Part.1.p. 231. [in Russian].

12. Popova, L. V. (1996). Problema samorealizatsii odarennykh zhenshchin [The problem of selfrealization of gifted women]. Psychology issues.No.2. pp. 31-42. [in Russian].

13. Rippon, Dzh. (2019).Gendernyy mozg [Gender brain]. Izdatelstvo "Fors". 400 p.[in Russian].

14. Stratehiia hendernoi rivnosti rady Yevropy na 2018-2023 roky [Council of Europe Gender Equality Strategy for 2018-2023]. Available at: https:// rm.coe.int/prems-041318-gbr-gender-equalitystrategy-2023-ukr-new2/16808b35a4 (accessed 16 July.2021). [in Ukrainian].

Стаття надійшла до редакції 03.09.2021

УДК 378:004.9

DOI:

Тетяна Мастеркова, викладач кафедри суспільно-гуманітарних дисчиплін Комунального закладу “Житомирський ОІППО” Житомирської обласної ради

\title{
ПРОФЕСІЙНІ СПІЛЬНОТИ ЯК ЧИННИК РОЗВИТКУ ФАХОВОЇ КОМПЕТЕНТНОСТІ ПЕДАГОГА
}

У статті охарактеризовано діяльність педагогічних професійних спільнот як чинник основи професійноособистісного становлення і розвитку педагога. Особливість діяльності професійних спільнот в умовах онлайнспілкування передбачає вдосконалення рівня цифрової компетентності учасників для організацї̈ родуктивного користування віртуальним простором спільноти. Стаття містить визначення професійних спільнот, розроблені основні критерії изиррових навичок для вимірювання рівня цииррової компетентності освітянина.

Ключові слова: професійні спільноти; професійна компетентність; професіоналізм; самопрезентація; саморозвиток; траєкторія професійного розвитку педагогічних працівників.

Табл. 1. Літ. 6.

Tatyana Masterkova, Lecturer of the Social and Humanitarian Branch of Science Department, Communal Educational Institution “Zhytomyr Regional In-Service Teachers' Training Institute”, Zhytomyr Regional Council

\section{TRADE UNIONS AS A FACTOR OF PROFESSIONAL DEVELOPMENT OF TEACHER COMPETENCES}

The article outlines the main activities of pedagogical professional communities to provide methodological support for the professional development of teachers in the period of online communication. Professional selfdetermination and self-realization of a teacher, along with professional orientation and socialization, act as constituent elements of the structure of his professional and personal formation and development.

Features of the creation and existence of professional communities of teachers in the online space involves improving the level of digital competence of participants to organize the productive use of virtual community space. Unlike traditional professional communities, which can exist without active voluntary communication, in online communities communication is a necessary prerequisite for stable support for the association of colleagues.

In the course of group activity of the community the self-organization of pedagogical workers on the principles of individual usefulness and satisfaction of inquiries of separate participants is provided. The intrinsic motivation of participants' communication needs and the development of approaches to assessing the teacher's professional growth explain the existence of an online community that brings people together in the long run.

In the course of the research the bases for long-term stable existence of modern online communities are studied, the organizational structure of the community is revealed, the typology of its members is carried out, an interaction, the results of community activity and their social effects are analyzed.

The article formulates the definition of professional communities, offers the main criteria for assessing digital skills to measure the level of digital competence of the educator. 
In a situation of a certain communication and information vacuum, the teacher seeks to compensate for the lack of professional communication through activities in professional communities, which not only creates stability in his life, but also helps to share their beliefs and interests with colleagues. Thanks to the existence of professional communities, adaptation to new forced living conditions is much easier and more effective.

Keywords: professional communities; professional competence; professionalism; self-presentation; selfdevelopment; the trajectory of professional development of teachers.

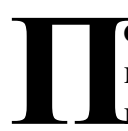
остановка проблеми. Самопрезентація педагогом власного досвіду, діяльність щодо апробування та поширення результативних практик, демонстрації професійних навичок, надання колегам методичної допомоги у плануванні й організації освітнього процесу, активна участь у діяльності професійних спільнот передбачена вимогами чинного Професійного стандарту за професіями "Вчитель початкових класів закладу загальної середньої освіти", "Вчитель закладу загальної середньої освіти”, "Вчитель 3 початкової освіти закладу загальної середньої освіти (з дипломом молодшого спеціаліста)", затвердженого наказом Мінекономіки від 23.12.2020 р. № 2736.

Аналіз останніх досліджень і публікацій. Самопрезентація педагога в професійній освітній спільноті має свою спрямованість. Питанням професійно-особистісного становлення і розвитку педагога присвячені роботи Г. Бабушкіна, Л. Вершиніної, І. Зимньої, М. Камінської, С. Клімової, А.Коростильової,А.Марюової,Л.Мітіної,Л.Михальцова, В. Шадрікова. Професійно-особистісне становлення педагога визначене як процес розвитку, самореалізації суб'єкта педагогічної діяльності в ході розв'язування ним професійних педагогічних завдань [3]. Водночас це динамічний процес розгортання психологічних властивостей і якостей особистості педагога, що виявляється у формуванні інтересу до педагогічної діяльності, оволодінні професійно необхідними і соціально значущими якостями. У професійних об'єднаннях створюються передумови для неперервного розвитку педагога.

Мета статті - охарактеризувати особливості діяльності професійних спільнот в умовах онлайнспілкування та визначення напрямів супроводу їх діяльності відповідно до вимог Професійного стандарту за професіями “Вчитель початкових класів закладу загальної середньої освіти”, "Вчитель закладу загальної середньої освіти", "Вчитель 3 початкової освіти закладу загальної середньої освіти (з дипломом молодшого спеціаліста)".

Виклад основного матеріалу. Узагальнення, систематизація, опис власних напрацювань як педагогічного досвіду, надання рекомендацій іншим вчителям достатньо важливе та складне завдання для педагога.
Законом України "Про освіту" (ст. 59) визначено, що професійний розвиток педагогічних працівників передбачає постійну самоосвіту, участь у програмах підвищення кваліфікації та будь-які інші види і форми професійного зростання [1]. Сучасний учитель має можливість самостійно обирати зміст і форму самопрезентації, визначати особливості структурування, збору і накопичення матеріалів, перетворювати обов'язкову вимогу поширення власного досвіду, демонстрації досягнень у професійних спільнотах відповідно до чинного Професійного стандарту за професіями "Вчитель початкових класів закладу загальної середньої освіти”, "Вчитель закладу загальної середньої освіти”, "Вчитель $з$ початкової освіти закладу загальної середньої освіти” [6]. Підготовка до атестації, участь у різних конкурсах, обмін досвідом вимагає від педагога здійснення рефлексії власних професійних досягнень, вмінь, напрацювань.

Зазначимо, що в сучасній педагогічній науці відсутні напрацювання системного аналізу щодо цифрового представлення професійного досвіду педагогом [4].

Об'єктивна реальність, пов'язана з пандемією, зумовила перехід практично всіх установ освіти на онлайнкомунікацію. Відтак, створення спільнот центрами професійного розвитку педагогів передбачає основною метою розбудову професійного синергетичного середовища, яке надихало б та мотивувало до професійного розвитку його учасників, забезпечувало психологічну підтримку, створювало умови для взаємодії, партнерства, методичного супроводу, обміну ідеями й освітніми практиками.

Професійну спільноту розуміємо як об'єднання педагогічних працівників за спільними інтересами, родом їх професійної (трудової) діяльності.

Мета діяльності таких спільнот полягає в організації систематизації та обгрунтуванні сучасних шляхів представлення вчителя як суб'єкта інноваційних процесів у контексті власного саморозвитку, методичних розробок, напрацювань, досвіду через:

- узагальнення аналітичних підходів до вимірювання професійних досягнень педагогів відповідно до вимог професійних стандартів;

- виявлення труднощів у прагненні вчителів до самовдосконалення, пошуку оптимальних шляхів ї подолання; 
- можливостіпопуляризації власного педагогічного досвіду в умовах цифрового середовища.

Професійні мережеві спільноти базуються на принципах звичайних професійних спільнот, використовують досвід їх діяльності. Ці два види спільнот схожі, але в мережевих спільнотах комунікація здійснюється за допомогою комп'ютерних технологій, що створює значимі переваги. Технології дистанційного спілкування полегшують обмін інформацією та їі зберігання, але мають особливості, які важливо враховувати педагогу.

Спілкування у професійних мережевих спільнотах - це не просто обмін якимись словами або ідеями за допомогою комп'ютерної мережі. Наприклад, воно не призначене для розваги, як у багатьох соціальних спільнотах, і не виконує функцій, пов'язаних з розвитком бізнесу, як в бізнес-спільнотах.

У професійних педагогічних спільнотах ефективність комунікації між учасниками багато в чому залежить від їх довіри один до одного. Довіра - це важлива складова взаємин, яка об'єднує колег у спільноті. Вона є передумовою для обміну знаннями, досвідом. Рішення, що приймаються в мережевих спільнотах їх учасниками, пов'язані з професійною діяльністю і вимагають відповідального підходу. І навпаки, в будь-яких соціальних мережевих спільнотах, пов'язаних з розвагами, там, де люди спілкуються просто для задоволення, довіра не відіграє настільки важливої ролі.

Організація якісної результативної діяльності професійних спільнот педагогічних працівників визначена пріоритетним напрямом діяльності Центру професійного розвитку педагогів м. Бердичів Житомирської області.

Основною метою центрів професійного розвитку педагогів, відповідно до Положення, визначено сприяння професійному розвитку педагогічних працівників, їх психологічній підтримці та консультуванню [5]. “Центри покликані організовувати консультування педагогічних працівників з питань планування та визначення траєкторії їх професійного розвитку, проведення супервізії, особливостей організації освітнього процесу за різними формами здобуття освіти, у тому числі з використанням дистанційних технологій навчання, впровадження компетентнісного, особистісно орієнтованого, діяльнісного, інклюзивного підходів до навчання здобувачів" [2; 4].

Тому 3 метою створення умов для результативної діяльності педагогів у професійних спільнотах, активного обміну ідеями та освітніми практиками, працівники Центру приділили увагу вивченню рівня цифрової компетентності учасників об’єднань для організації продуктивного користування віртуальним простором спільноти (таблиця 1).

Реалізація процесу взаємодії учасників

Таблиця 1.

Оріснтовні критерії цифрових навичок освітянина ХX ст.

\begin{tabular}{|c|c|}
\hline Цифрові навички & Інструменти \\
\hline Запис і редагування аудіо, відео & $\begin{array}{l}\text { Soundcloud } \\
\text { Audioboo } \\
\text { Vocaroo } \\
\text { Clyp }\end{array}$ \\
\hline $\begin{array}{l}\text { Створення анотованого, інтерактивного та цікавого за змістом } \\
\text { відео }\end{array}$ & $\begin{array}{l}\text { VideoNotes } \\
\text { ТЕД Ed } \\
\text { Edpuzzle } \\
\text { WeVideo } \\
\text { Magisto } \\
\text { Piktochart } \\
\text { Canva } \\
\text { Google Draw } \\
\text { Glogster } \\
\text { Thinglink }\end{array}$ \\
\hline $\begin{array}{l}\text { Використання веб-сайтів, соціальних мереж для створення персонального } \\
\text { освітнього середовища і спільне використання ресурсів } 3 \text { класом учнів }\end{array}$ & $\begin{array}{l}\text { Facebook } \\
\text { Гугл плюс } \\
\text { Linkedin } \\
\text { Diigo } \\
\text { Викопати це } \\
\text { Pinterest } \\
\text { Edshelf } \\
\text { Educlipper } \\
\text { Symbaloo }\end{array}$ \\
\hline
\end{tabular}


Продовження таблиці 1.

\begin{tabular}{|l|l|}
\hline Використання блогів і вікі для створення освітнього простору за & Blogger \\
участю учнів/студентів & Wordpress \\
& Edublog \\
\hline Створення презентацій & Kidblog \\
& Wikispaces \\
Weebly \\
\hline Створення цифрового портфоліо & GoogleПрезентація \\
\hline Xaйку Палуба \\
Prezi \\
\hline
\end{tabular}

професійних мережевих спільнот забезпечується через:

- форуми (для ведення асинхронної комунікації і формування підгрупи, пов’язаної з конкретною темою);

- чати (для обговорення проблеми, швидкого налагодження зв'язків у співтоваристві);

- графічні чати, аудіо та відео (для відчуття залученості до процесу комунікації);

- списки розсилки (для доставки всім учасникам повідомлень, пов'язаних 3 новинами спільноти).

Для поліпшення комунікації у співтоваристві, дотримання авторських прав, безпеки учасників, свободи колег у вираженні думок роботою спільноти керує лідер-модератор. На нього покладається розподіл ролей учасників об'єднання, що сприяє зв'язку наявного досвіду 3 набутим, полегшує процес спілкування. Лідер змінюється у спільноті відповідно до актуальності методичних завдань.

Проведене опитування потенційних учасників створюваних професійних спільнот виявило, що майбутні члени об'єднання належать до різних груп за віком, досвідом, уподобаннями. Окремі члени професійної спільноти зазначали, що одним iз аргументів спробувати себе у ролі учасника певного об'єднання було бажання “перемогти себе”, тому що сам формат онлайнспілкування спонукає людину вийти із зони усамітнення та спілкуватися з іншими учасниками за допомогою незвичних для неї методів, вийти у громадський публічний простір через демонстрацію i самопрезентацію в соціальній мережі. Активна участь у роботі професійної спільноти спонукала багатьох педагогів вдосконалювати свої вміння і навички користувача інтернету, адже підтверджувати рівень майстерності необхідно не для формального вступу до спільноти, а щоб успішно в ній працювати, вміти продемонструвати свої досягнення, поділитися цікавою інформацією.

Не кожен учасник має достатній рівень технологічної компетентності, щоб користуватися віртуальним простором. Тому на початку діяльності спільноти враховується наявність фактичних аутсайдерів, які мають мало підписників, не вміють знімати відеоролики гарної якості, інтереси активних учасників, що знімають періодичні відео про саморозвиток і зростання власної майстерності й авторитетних членів об'єднання, педагогів, які створять ядро спільноти і формуватимуть загальну думку щодо більшості питань.

Відсутність у мережевому співтоваристві лідера-модератора робить процес комунікації спільноти неорганізованим, некерованим, стихійним, що відхиляється від своїх цілей, відповідно - знижує ефективність взаємодії.

Лідери керують процесом комунікації у співтоваристві, спрямовують його в потрібне русло, формують правила і норми взаємодії. При цьому часто лідерство виникає ситуативно через активну комунікацію учасників. Більшість учасників спільноти є експертами у викладанні певного навчального предмету, беруть активну участь у щоденній діяльності об'єднання, допомагають фіксувати, систематизувати, здійснювати обмін інформацією в професійному мережевому співтоваристві. Учасники спільноти, очевидно, проявлятимуть різний рівень активності, зокрема можуть просто споживати запропоновану інформацію.

Зрозуміло, що очні зустрічі, засідання дають можливість обговорити те, що не обговорюється в інтернеті, де присутні певні вимоги, традиції спілкування. Онлайнкомунікація вимагає позитивного настрою, формування образу учасника як активного і компетентного члена 
спільноти. Тому обговорення проблемних питань після онлайнспілкування допомагає відчути взаємне розуміння та підтримку, які формують єдність спільноти, сприяють іiі самоорганізації. Ефективність діяльності спільноти забезпечується добровільними й ініціативними діями учасників, що є основним принципом іï функціонування. Все це створює вільне від негативу поле спілкування, здатне стати емоційно безпечним, комфортним майданчиком для кожного охочого.

Учасники об'єднань визнають, що розміщені матеріали колег сприяли розвитку їх професійної компетентності, допомагали нарощувати майстерність, вивчати новинки методики, знайомитись із закордонним досвідом.

Таким чином, аналіз підходу до супроводу професійного становлення педагога в процесі його самореалізації через діяльність у складі професійних спільнот засвідчує, що в суспільстві формуються зміни вимог до професійного розвитку педагога: від професіонала, що виконує комплекс професійних функцій, від вчителяпредметника до самореалізованої особистості здатної сприяти самореалізації своїх учнів.

Висновки. Отже, дослідження нових підходів в організації діяльності професійних педагогічних спільнот дає підставу для такого висновку: крім розвитку професійних навичок учасників, спільнотою активно стимулюється їх саморозвиток.

Діяльність у професійних онлайнспільнотах вимагає певного рівня цифрової компетентності учасників для організації продуктивної взаємодії у віртуальному просторі.

Крім того, взаємодія між учасниками спільноти завжди відбувається в рамках спеціалізованого педагогічного дискурсу, завдяки чому одночасно формується колективна ідентичність групи, створюється потужний загін однодумців.

\section{ЛIТЕРАТУРА}

1. Закон України “Про освіту”. Відомості Верховної ради України. 2019. №2657-VIII. 2661 - VIII. URL: https:/ zakon.rada.gov.ua/laws/show/2145-19

2. Концепція реалізації державної політики у сфері реформування загальної середньої освіти "Нова українська школа" на період до 2029 року. Розпорядження Кабінету Міністрів України. 14.12.2016 p. № 988-p. URL: http://osvita.ua/legislation/Ser_osv/54258/
3. Концепція розвитку педагогічної освіти. Наказ Міністерства освіти і науки України. 16.07.2018 р. № 776. URL: https://mon.gov.ua/ua/npa/pro-zatverdzhennyakoncepciyi-rozvitku-pedagogichnoyi-osviti

4. Мастеркова Т.В. Професійна компетентність: сучасні формати поширення педагогічного досвіду та методичних розробок. Молодь і ринок. №3 (189), 2021. URL: http://mir.dspu.edu.ua/article/view/234267

5. Положення про центр професійного розвитку педагогічних працівників. Постанова Кабінету Міністрів України. 29.07.2020 p. № 672. URL: https:// zakon.rada.gov.ua/laws/show/672-2020-\%D0\%BF\#n10

6. Реєстр професійних стандартів. Сайт Мінекономіки. 2021. URL: https://www.me.gov.ua/Documents/ Detail?lang=uk-UA\&id=22469103-4e36-4d41-b1bf$\underline{288338 \mathrm{~b} 3 \mathrm{c} 7 \mathrm{fa} \& \text { title }=\text { RestrProfesiinikhStandartiv }}$

\section{REFERENCES}

1. Zakon Ukrainy "Pro osvitu" [Law of Ukraine "On Education"]. Available at: https://zakon.rada.gov.ua/laws/ show/2145-19/. [in Ukrainian].

2. Kontseptsiia realizatsii derzhavnoi polityky u sferi reformuvannia zahalnoi serednoi osvity "Nova ukrainska shkola" na period do 2029 roku [The concept of implementation of state policy in the field of reforming general secondary education "New Ukrainian School" for the period up to 2029]. Order of the Cabinet of Ministers of Ukraine. vailable at: http://osvita.ua/legislation/Ser osv/ 54258/. [in Ukrainian].

3. Kontseptsiia rozvytku pedahohichnoi osvity [The concept of development of pedagogical education. Order of the Ministry of Education and Science of Ukraine. 16.07.2018 № 776]. Order of the Ministry of Education and Science of Ukraine. 16.07.2018 No. 776. Available at: https:/ /mon.gov.ua/ua/npa/pro-zatverdzhennya-koncepciyirozvitku-pedagogichnoyi-osviti. [in Ukrainian].

4. Masterkova, T.V. Profesiina kompetentnist: suchasni formaty poshyrennia pedahohichnoho dosvidu ta metodychnykh rozrobok [Professional competence: modern formats of dissemination of pedagogical experience and methodical developments].Youth \& market. No. 3 (189), 2021. Available at: http://mir.dspu.edu.ua/article/ view/234267. [in Ukrainian].

5. Polozhennia pro tsentr profesiinoho rozvytku pedahohichnykh pratsivnykiv [Regulations on the center of professional development of pedagogical workers]. Resolution of the Cabinet of Ministers of Ukraine. 29.07.2020. No. 672. Available at: https://zakon.rada.gov.ua/ laws/show/672-2020-\%D0\%BF\#n10/. [in Ukrainian].

6. Reiestr profesiinykh standartiv [Register of professional standards]. Website of the Ministry of Economy 2021. Available at: https://www.me.gov.ua/Documents/Detail?lang=ukU A \& i d = 22469103-4 e 36-4d 41 - b 1 b f 288338b3c7fa\&title=RestrProfesiinikhStandartiv/.[in Ukrainian].

Стаття надійшла до редакції 18.08.2021

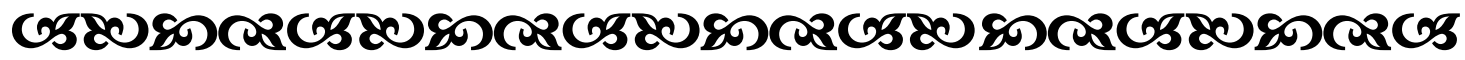

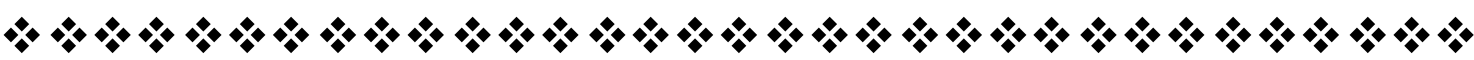

